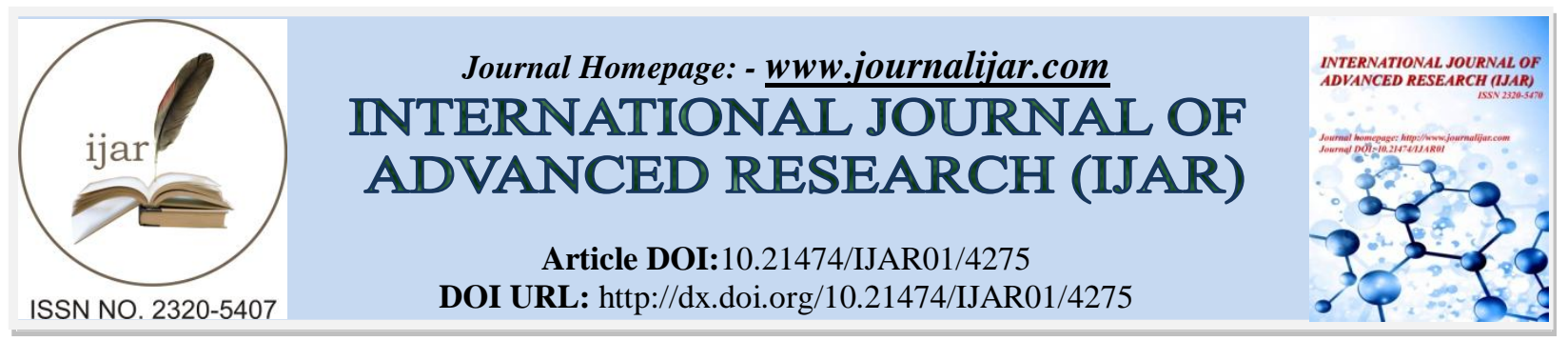

RESEARCH ARTICLE

\title{
A CROSS SECTIONAL ASSESSMENT OF KNOWLEDGE, ATTITUDE AND PRACTICE TOWARDS HEPATITIS B AMONG FEMALE HEALTH CARE WORKERS OF KASHMIR VALLEY.
}

Rabbanie Tariq Wani ${ }^{1}$, Hibba Dar ${ }^{2}$, Khalid Javid Bhat ${ }^{3}$ and S.Muhammad Salim Khan ${ }^{4}$.

1. Department of Community Medicine, Government Medical College, Srinagar, J\&K, India

2. J \& K Health Services, J \& K, India

3. Department of Internal Medicine, Government Medical College, Srinagar, J \& K, India

4. Head of Department, Department of Community Medicine, Government Medical College, Srinagar, J\&K, India

\section{Manuscript Info}

Manuscript History

Received: 28 March 2017

Final Accepted: 30 April 2017

Published: May 2017

Key words:-

Knowledge, Attitude, Practice, Hepatitis

B, Healthcare workers, Kashmir.

\section{Abstract}

Background: Hepatitis B (HB) is a serious global public health problem. This study aims to evaluate Knowledge, Attitude and Practice (KAP) towards Hepatitis B (HB) among female health care workers of Kashmir valley

Methods: A cross sectional, descriptive study was undertaken. Around four hundred female multipurpose health care workers (aged 18 years and above) were approached for the study. KAP towards HB was assessed by using a pre validated questionnaire. Descriptive statistics were used for elaborating workers demographic characteristics. Inferential statistics (Mann-Whitney $\mathrm{U}$ test and Kruskal Wallis test) were used for comparison while Pearson's correlation was used to identify association between the study variables. All analyses were performed using SPSS 20.

Results: Out of 450 distributed questionnaires, 49 were rejected for not correctly filling in the details.401 respondents with the mean age of $28.9 \pm 4.3$ year. $249(30.9 \%)$ had $10^{\text {th }}$ grade level of education and $221(27.4 \%)$ had an income 10,001-15,001 per month. Mean scores for knowledge, attitude and practice were $14.15 \pm 4.6,5.42 \pm 1.1$ and $5.76 \pm 1.5$ respectively. Significant and positive linear correlations between knowledge-attitude $(r=0.249, \mathrm{p}<0.001)$ knowledge-practice $(r=0.174, p<0.001)$ and attitude-practice $(r=0.134, p<0.05)$ were observed. Age was the only variables significantly associated with mean KAP of the study respondents.

Conclusion: Results from the current study heighted average KAP of female multipurpose health care workers towards Hepatitis B. The positive linear correlations reaffirms that better knowledge can lead to positive attitude and subsequently in good practices. This will further help in prevention and management of HB. Therefore, extensive health educational campaign should be provided to health care workers, general population and especially to the residents of rural areas.

Copy Right, IJAR, 2017,. All rights reserved. 


\section{Background:-}

Hepatitis B (HB) is a serious and common infectious disease of the liver. The World Health Organization (WHO) in 2009 reported HB to infect nearly 2 billion people around the globe. Furthermore, out of those 2 billion, 350 million suffered from chronic, lifelong infection [1]. Moreover, an estimated 15-40\% of chronic HB carriers were susceptible to develop liver cirrhosis and hepatocellular carcinoma [2,3]. HB is a confronting ailment and results in 0.6 million deaths annually [4,5]. Although HB is classified as 'disease of priority,' there is an incessant increase in detection of new cases worldwide [6]. Furthermore, HB is widespread in the Asia Pacific region and 10 to 15 million of the population suffer from this disease [7-9]. Similar to what is reported worldwide, the incidence of HB infection is on continuous rise in India [10]. The pervasiveness of HB ranges between 2 to $8 \%$ in Indian population and varies from region to region [11]. In, the prevalence of HB is reported lower (2-5\%) as compared with the rural areas which can range from where $30-35 \%$ [12]. Based on these statistics, India is classified as a region of 'intermediate risk' towards HB by WHO [1]. The health system of India consists of both private and public sectors. The public health sector serves nearly $75 \%$ of the Indian population comprising rural areas, whereas the private sector comprises more than $32 \%$ of national bed strength lies in the 150 plus private corporate hospitals viz. Tatas, Apollo, Wockhardt, Escorts, Max India, Fortis, Piramal, Ispat, Duncan,Escorts etc[13]. Knowledge, attitude, and practice (KAP) surveys are representative of a specific population to collect information on what is known, believed and done in relation to a particular topic, and are the most frequently used study tool in health-seeking behavior research [14]. Knowledge is usually assessed in order to see how far community knowledge corresponds to biomedical concepts [15]. Typical questions include knowledge about causes and symptoms of the illness under investigation. People reported knowledge which deviates from biomedical concepts is usually termed as 'beliefs' [16]. Attitude has been defined as "a learned predisposition to think, feel and act in a particular way towards a given object or class of objects" [17]. As such, attitude is a product of a complex interaction of beliefs, feelings, and values. Practices in KAP surveys usually enquire about the use of preventive measures or different health care options. Normally, hypothetical questions are asked, therefore it hardly permits statements about actual practices, rather, it yields information on people's behaviors or on what they know should be done [18].As discussed earlier, the frequency of HB is increasing progressively worldwide, prevention is considered as one best way to safeguard populations' health. Deterrence can also lead to decreased spread of HB virus thus reducing the chances of disease conduction. Prevention against any disease is proportional to KAP of the population and is reflective of the importance that is paid to health related issues by the society. Therefore, KAP studies play an imperative role in determining the ambiguities of a society and are widely used in population reported assessment research worldwide. To the contrary, there is paucity of data from Kashmir and KAP towards HB among female multipurpose health workers who are the ground level workers having the first interaction with population in Kashmir is never explored. In spite of the efforts made by authorities to raise knowledge and awareness about HB, no progress is reported. In the present scenario, there is a need to assess the KAP status of healthy individuals towards HB so that the information can be used to develop a better and need based program for the society. The current study aimed to assess knowledge, attitudes and practices (KAP) of healthy population towards HB from Anantnag \& Baramulla districts of Kashmir valley who had come to attend a series of workshops under Rashtriya Kishore Swasthya Karyakaram held in Department of Community Medicine, Government Medical College,Srinagar.

\section{Methods:-}

\section{Study design and settings:-}

This descriptive study was designed as questionnaire based, cross sectional analysis. Female multipurpose health care workers from Anantnag \& Baramulla districts of Kashmir division in Jammu \& Kashmir state of India were targeted for the study. The study questionnaire was distributed at conference hall of Department of Community Medicine, GMC, Srinagar. Participants were requested to answer the questionnaire on spot and were subsequently collected after completion.

\section{Study sample:-}

By employing convenience sampling method, 405 respondents were targeted for the study. The study was conducted from March 2015 to December 2015. Female Multipurpose health care workers aging 18 years and above were included in the study. 


\section{Ethical Approval:-}

This study was performed according to the ethical guidelines for biomedical research on human participants [19]. Permission was taken from the Government Medical College, Srinagar ethical committee. Written consent was also taken from the respondents before initiation of the research.

\section{Study Instrument:-}

A self administered, 35 itemed questionnaire comprising of four sections was used for data collection. In addition to the demographic data, 20 questions explored knowledge towards HB, 7 questions focused on attitude and 8 questions addressed practices towards HB. Respondents were asked to answer in limited as well as multiple choice formats. The primary version of the questionnaire was developed through extensive literature review in English language $[14,20]$.It was later translated into Urdu language by using standard translating procedures [21,22]. The Urdu version of the questionnaire was tested for its reliability and validity. Internal consistency was assessed by using Cronbach's alpha $(\alpha=0.7)$ and was found to be in acceptable ranges [23] The questionnaire was than piloted with 30 respondents for its acceptability and consistency. Little modification was needed after the pilot testing. Data from the pilot study was not included in the final analysis. As the consistency and validity of the study questionnaire was stabilized, the instrument was made available for data collection. Although, we gave an open option to respondents whether they wanted the questionnaire in English or Udru language.

\section{Statistical Analysis:-}

Descriptive statistics were used to illustrate respondents' demographic characteristics. Categorical variables were measured as percentages while continuous variables were expressed as mean \pm standard deviation. The KolmogrovSmirnov test was applied to declare the nature of data distribution. Inferential statistics (Mann-Whitney $U$ test and Kruskal Wallis tests) were used to assess the difference while Pearson's correlation coefficient was used to evaluate the relationship between the study variables. A $p$ value of $<0.001$ was taken as significant for Mann-Whitney U test and Kruskal Wallis test. In addition, $\mathrm{p}<0.05$ was taken as significant for correlation analysis. IBM Statistical Package for Social Sciences (SPSS) v. 20.0 was used for data analysis. 


\begin{tabular}{|c|c|c|}
\hline Characteristics & $\mathrm{N}$ & $\%$ \\
\hline \multicolumn{3}{|l|}{ Age $(28.9 \pm 4.3)$} \\
\hline $19-24$ & 20 & 5.0 \\
\hline $25-30$ & 293 & 73.1 \\
\hline $31-36$ & 60 & 15 \\
\hline $37-43$ & 28 & 7.0 \\
\hline \multicolumn{3}{|l|}{ Gender } \\
\hline Female & 401 & 100 \\
\hline \multicolumn{3}{|l|}{ Education } \\
\hline Religious only & 4 & 0.9 \\
\hline Matric (Up to $10^{\text {th }}$ grade) & 249 & 62.0 \\
\hline Intermediate (Up to $12^{\text {th }}$ grade) & 72 & 17.9 \\
\hline Graduation & 76 & 18.9 \\
\hline \multicolumn{3}{|l|}{ Income* } \\
\hline$<$ INR 5000 & 21 & 5.1 \\
\hline $5001-10000$ & 43 & 10.6 \\
\hline $10001-15000$ & 221 & 55.1 \\
\hline $15001-20000$ & 44 & 10.9 \\
\hline$>20000$ & 72 & 17.9 \\
\hline \multicolumn{3}{|l|}{ Locality } \\
\hline Urban & 71 & 17.7 \\
\hline Rural & 330 & 82.2 \\
\hline \multicolumn{3}{|l|}{ Source of HB information } \\
\hline Newspapers \& Magazines & 143 & 35.6 \\
\hline Health workers & 206 & 51.3 \\
\hline TV, Radio \& Internet & 34 & 8.4 \\
\hline Never heard of & 18 & 4.4 \\
\hline
\end{tabular}

\section{Results:-}

Demographic Characteristics:-

A total of 450 questionnaires were distributed and 405 were received filled completely. The Kolmogrov-Smirnov test revealed non normal distribution of the data. Mean age of the study participants was $28.9 \pm 4.3$ years with 330 $(82.2 \%)$ having rural residency. Two hundred and forty nine $(30.9 \%)$ had $10^{\text {th }}$ grade level of education and 221(55.1\%) were having a monthly income of 10,001-15001 Indian Rupees (INR). The major source of information regarding HB was from colleagues (health workers) 206 (51.3\%), followed by $143(35.6 \%)$ by HB information Newspapers \& magazines(Table 1). 


\begin{tabular}{|c|c|c|}
\hline Hepatitis B Knowledge Items & Yes & No \\
\hline & $\mathrm{N}(\%)$ & $\mathrm{N}(\%)$ \\
\hline Have you ever heard of a disease termed as Hepatitis? & $345(86)$ & $56(14)$ \\
\hline Have you ever heard of a disease termed as Hepatitis B? & $365(91)$ & $36(9)$ \\
\hline Is Hepatitis B is a viral diseases & $321(80)$ & $44(11)$ \\
\hline Can Hepatitis B affect liver function & $353(88)$ & $12(3)$ \\
\hline Can Hepatitis B cause liver Cancer? & $298(74.3)$ & $67(16.7)$ \\
\hline Can Hepatitis B affect any age group? & $257(64.1)$ & $108(26.9)$ \\
\hline $\begin{array}{l}\text { The early symptoms of Hepatitis B are same like cold and flu (fever, running } \\
\text { nose, cough) }\end{array}$ & $115(28.7)$ & $250(62.3)$ \\
\hline Jaundice is one of the common symptoms of Hepatitis B? & $349(87)$ & $16(4)$ \\
\hline Are nausea, vomiting and loss of appetite common symptom of Hepatitis B? & $324(80.8)$ & $41(10.2)$ \\
\hline Are there no symptoms of the Hepatitis B in some of the patients? & $242(60.3)$ & $123(30.7)$ \\
\hline $\begin{array}{l}\text { Can Hepatitis B be transmitted by un-sterilized syringes, needles and surgical } \\
\text { instruments? }\end{array}$ & $329(82)$ & $36(9.0)$ \\
\hline Can Hepatitis B be transmitted by contaminated blood and blood products? & $337(84.0)$ & $28(7.0)$ \\
\hline $\begin{array}{l}\text { Can Hepatitis B be transmitted by using blades of the barber/ear and nose } \\
\text { piercing? }\end{array}$ & $297(74.1)$ & $68(16.9)$ \\
\hline Can Hepatitis B be transmitted by unsafe sex? & $231(57.6)$ & $134(33.4)$ \\
\hline Can Hepatitis B be transmitted from mother to child? & $298(74.3)$ & $67(16.7)$ \\
\hline $\begin{array}{l}\text { Can Hepatitis B be transmitted by contaminated water/food prepared by } \\
\text { person suffering with these infections? }\end{array}$ & $170(42.4)$ & $195(48.6)$ \\
\hline Is Hepatitis B curable/treatable? & $332(82.8)$ & $33(8.2)$ \\
\hline Can Hepatitis B be self-cured by body? & $127(31.7)$ & $238(59.4)$ \\
\hline Is vaccination available for Hepatitis $B$ ? & $361(90.0)$ & $4(1.0)$ \\
\hline Is specific diet is required for the treatment of Hepatitis B? & $224(55.9)$ & $141(35.2)$ \\
\hline
\end{tabular}

Assessment of knowledge towards Hepatitis B:-

Table 2 describes the responses of the participants towards HB knowledge. Knowledge was assessed by questions focusing on HB etiology, sign and symptoms, transmission, treatment and management. Each response was scored as 'yes' or 'no'. The scoring range of the questionnaire was 20 (maximum) to 0 (minimum). A cut off level of $\leq 14$ was considered as poor whereas > 14 was considered as adequate knowledge about HB. Knowledge scores for individuals were calculated and summed up to give the total knowledge score. Out of the 401 participants, 293 $(73.1 \%)$ were within the good knowledge range whereas $108(26.9 \%)$ showed poor knowledge about HB. It is important to notice here 36 respondents had not ever heard the name of Hepatitis or Hepatitis-B being a health care worker and thus could not attempt any of the questions after that. Poor knowledge was apparent in responses to questions relating to symptoms like age criteria where in the correct response was $64.1 \%$.Knowledge about transmission of HB via unsafe sex where in the correct response were only $33.4 \%$ and through contaminated food wherein correct response rate was only $48.6 \%$. Regarding treatment of HB only $59.4 \%$ gave correct response and treatment in relation to diet only $55.9 \%$ gave correct response. Correct answers 86.0, 91.0, 88.0 and 90.0\% were highest in response to questions 1, 2, 4 and 19 respectively. The mean knowledge score for the entire study cohort was $14.15 \pm 4.66$.

\section{Assessment of attitude towards:-}

Hepatitis B Attitude towards HB was assessed by asking seven questions as shown in Table 3. Each question was labeled with positive or negative attitude. A score of 1 was given to positive while 0 was given to negative attitudes with a score range of maximum of 7 to a minimum of 0 . The scale classified attitude as positive with score $>4$ and negative $\leq 4$. Out of 365 nearly half of the respondent $182(45.4 \%)$ believed that they can never get infected with HB. One hundred ninety $(47.4 \%)$ respondents stated that they will be fearful to get infected with HB. Fifty Seven respondents $(14.2 \%)$ were of opinion to use complementary and alternative system in case of HB infection. In addition, $315(78.5 \%)$ agreed to consult a physician as their first choice of treatment. However, respondents were 
ready to disclose their disease to their spouse $(n=24,5.9 \%)$ and parents $(n=22,5.4 \%)$. Over all the respondents had a positive attitude towards Hepatitis B with mean score of $5.42 \pm 1.10$.

\section{Assessment of practices towards Hepatitis B:-}

Practices towards HB were assessed by asking eight questions as shown in Table 4. Each question was labeled with good or poor practice. A score of 1 was given to good while 0 was given to bad practice with a score range of maximum of 8 to a minimum of 0 . The scale classified practice as good with score $>5$ and poor $\leq 5$.Majority of the respondents, $222(55.4 \%)$ never went for HB screening and $74(18.5 \%)$ stated a negative immunized status against HB. It was interesting to know that $24(6.0 \%)$ never asked for a new syringe when required, while $341(85 \%)$ agreed with the statement that they ask for screening of blood and blood products before transfusion. $24(6.0 \%)$ respondents either never asked the barber to use new blade, or for safe and clean equipment for nose and ear piercing. However, on the contrary majority of the study participants $(n=287,71.6 \%)$ revealed that they do not avoid meeting a person infected with HB. Majority $325(81.0 \%)$ agreed that they will go for further investigation and treatment if they are infected with HB. In addition, a number of respondents $(n=98,24.4)$ have never attended any educational program on HB. The mean score for HB related practices was $5.71 \pm 1.5$ revealing good practices among the study participants. 


\begin{tabular}{|c|c|c|}
\hline Hepatitis B Attitude Items & $\mathrm{N}(401)$ & $\%$ \\
\hline \multicolumn{3}{|l|}{ Do you think you can get Hepatitis B? } \\
\hline Yes & 183 & 45.6 \\
\hline No & 182 & 45.4 \\
\hline \multicolumn{3}{|c|}{ What would be your reaction if you found that you have Hepatitis B? } \\
\hline Fear* & 190 & 47.4 \\
\hline Shame & 8 & 1.9 \\
\hline Surprise & 29 & 7.2 \\
\hline Sadness & 138 & 34.4 \\
\hline \multicolumn{3}{|l|}{ Who would you talk to about your illness? } \\
\hline Physician & 315 & 78.5 \\
\hline Spouse & 24 & 5.9 \\
\hline Parents & 22 & 5.4 \\
\hline Child & 0.0 & 0.0 \\
\hline Other Relatives & 0.0 & 0.0 \\
\hline Friends & 0.0 & 0.0 \\
\hline No one ${ }^{*}$ & 4 & 0.9 \\
\hline \multicolumn{3}{|c|}{ What will you do if you think that you have symptoms of Hepatitis $B$ ? } \\
\hline Go to Health facility* & 308 & 76.8 \\
\hline Go to Hakeem & 0.0 & 0.0 \\
\hline Go to Homeopath & 57 & 14.2 \\
\hline Go to Traditional healer & 0.0 & 0.0 \\
\hline \multicolumn{3}{|c|}{$\begin{array}{l}\text { If you had symptoms of Hepatitis B, at what stage you will go to the health } \\
\text { facility? }\end{array}$} \\
\hline Own treatment fails & 16 & 3.9 \\
\hline After 3-4 weeks of the appearance of symptoms & 12 & 2.9 \\
\hline Soon as I realize the symptoms are of Hepatitis B* & 313 & 78.0 \\
\hline Will not go to physician & 24 & 5.9 \\
\hline \multicolumn{3}{|c|}{ How expensive do you think is the diagnosis and treatment of Hepatitis B? } \\
\hline Free & 52 & 12.9 \\
\hline Reasonable & 88 & 21.9 \\
\hline Somewhat expensive & 68 & 16.9 \\
\hline Expensive & 89 & 22.1 \\
\hline Don't know & 68 & 16.9 \\
\hline \multicolumn{3}{|c|}{ What worries you most if you will be diagnosed with Hepatitis B } \\
\hline Fear of death & 153 & 38.1 \\
\hline Fear of disease spread to family & 116 & 28.9 \\
\hline Cost of treatment & 58 & 14.4 \\
\hline Isolation from the society ${ }^{*}$ & 38 & 9.4 \\
\hline
\end{tabular}

${ }^{*}$ Positive attitude, ${ }^{\ddagger}$ Negative attitude.

Note: Attitude was assessed by giving 1 to positive and 0 to negative attitude. The scale classified attitude as positive with score $>4$ and negative $\leq 4$. Over all the respondents had a positive attitude towards Hepatitis B with mean score of 5.42 \pm 1.10 . 


\begin{tabular}{|l|c|c|}
\hline Table 4 Practice related to Hepatitis B & & \\
\hline Hepatitis B Practice Items & Yes & No \\
\hline & $143(35.7)$ & $\mathbf{N}(\%)$ \\
\hline Have you done screening for Hepatitis B? & $283(70.6)$ & $74(18.5)$ \\
\hline Have you got yourself vaccinated against Hepatitis B? & $333(83.0)$ & $24(6.0)$ \\
\hline Do you ask for a new syringe before use? & $341(85.0)$ & $16(4.0)$ \\
\hline Do you ask for screening of blood before transfusion? & $333(83.0)$ & $24(6.0)$ \\
\hline $\begin{array}{l}\text { Do you ask your barber to change blade/Or for safe equipments for ear } \\
\text { and nose piercing? }\end{array}$ & $325(81.0)$ & $32(8.0)$ \\
\hline $\begin{array}{l}\text { In case you are diagnosed with Hepatitis B, would you go for further } \\
\text { investigation and treatment? }\end{array}$ & $70(17.5)$ & $287(71.6)$ \\
\hline Do you avoid meeting Hepatitis B patients? & $259(64.6)$ & $98(24.4)$ \\
\hline $\begin{array}{l}\text { Have you ever participated in health education program related to } \\
\text { Hepatitis B? }\end{array}$ & & \\
\hline
\end{tabular}

Note: Practice was assessed by giving 1 to positive and 0 to negative attitude.

The scale classified practice as good with score $>5$ and poor $\leq 5$. Over all the respondents reported to have good practice towards Hepatitis $B$ with mean score of $5.7 \pm 1.5$.

\begin{tabular}{|c|c|c|c|c|c|c|c|c|}
\hline Description & $\begin{array}{c}N \\
(401)\end{array}$ & $\begin{array}{l}\text { Knowledge Score } \\
\text { (Mean } \pm \text { S.D) }\end{array}$ & $\begin{array}{c}\mathrm{P}- \\
\text { value }\end{array}$ & $\underset{(365)}{N}$ & $\begin{array}{l}\text { Attitude Score } \\
\text { (Mean } \pm \text { SD) }\end{array}$ & $\begin{array}{c}\mathrm{P}- \\
\text { value }\end{array}$ & $\begin{array}{l}\text { Practice Score } \\
\text { (Mean } \pm \text { SD) }\end{array}$ & $\begin{array}{c}\mathrm{P} \text { - } \\
\text { value }\end{array}$ \\
\hline \multicolumn{9}{|l|}{ Age* } \\
\hline $19-24$ & 20 & $16.8(0.4)$ & .000 & 20 & $5.6(0.8)$ & 0.003 & $5.4(0.5)$ & 0.006 \\
\hline $25-30$ & 293 & $13.9(4.8)$ & & 265 & $5.3(1.1)$ & & $5.6(1.4)$ & \\
\hline $31-36$ & 60 & $13.4(5.2)$ & & 52 & $5.3(1.0)$ & & $6.3(0.8)$ & \\
\hline $37-43$ & 28 & $16.1(0.8)$ & & 28 & $6.1(0.8)$ & & $5.1(2.5)$ & \\
\hline \multicolumn{9}{|l|}{ Education* } \\
\hline Religious only & 4 & $14.0(0.0)$ & 0.143 & 4 & $4.0(0.0)$ & 0.000 & $7.0(0.0)$ & 0.000 \\
\hline $10^{\text {th }}$ grade & 249 & $14.3(4.6)$ & & 229 & $5.1(1.0)$ & & $5.4(1.4)$ & \\
\hline Intermediate & 72 & $13.4(5.8)$ & & 60 & $6.2(0.8)$ & & $5.7(1.9)$ & \\
\hline Graduate & 76 & $14.3(3.5)$ & & 72 & $5.5(1.0)$ & & $5.7(1.5)$ & \\
\hline \multicolumn{9}{|l|}{ Income* } \\
\hline$<5000$ & 21 & $15.3(0.4)$ & 0.009 & 21 & $5.3(1.3)$ & 0.002 & $4.5(3.2)$ & 0.006 \\
\hline $5001-10000$ & 43 & $12.2(6.5)$ & & 34 & $5.7(0.6)$ & & $6.5(1.1)$ & \\
\hline $10001-15000$ & 221 & $14.6(4.6)$ & & 202 & $5.4(1.0)$ & & $5.7(1.0)$ & \\
\hline $15001-20000$ & 44 & $14.6(2.1)$ & & 44 & $4.8(1.2)$ & & $5.4(1.3)$ & \\
\hline$>20000$ & 72 & $13.1(4.8)$ & & 64 & $5.6(0.9)$ & & $5.8(1.8)$ & \\
\hline \multicolumn{9}{|l|}{ Locality** } \\
\hline Urban & 71 & $12.9(4.8)$ & 0.001 & 63 & $5.5(1.2)$ & 0.218 & $5.6(2.1)$ & 0.298 \\
\hline Rural & 330 & $14.4(4.5)$ & & 302 & $5.3(1.0)$ & & $5.7(1.3)$ & \\
\hline Total & 405 & $14.1(4.6)$ & & 365 & $5.4(1.1)$ & & $5.7(1.5)$ & \\
\hline
\end{tabular}

Association of demographic characteristics and mean KAP Scores:-

The association of demographic characteristics and mean KAP scores is presented in Table 5. Among the demographic variables, age was significantly associated with mean Knowledge \& Attitude scores $(\mathrm{p}<0.001)$, while education was significantly associated with mean Attitude \& practice scores $(\mathrm{p}<.001)$, income was significantly associated with mean attitude scores only and locality was significantly associated with Knowledge scores only $(\mathrm{p}<.05)$ 
Correlation between knowledge, attitude and practice:-

Correlations were interpreted using the following criteria: $0-0.25=$ weak correlation, $0.25-0.5=$ fair correlation, $0.5-0.75=$ good correlation and greater than $0.75=$ excellent correlation [24]. The correlation revealed significant positive linear correlations between knowledge-attitude $(\mathrm{r}=0.249, \mathrm{p}<0.001)$ knowledge-practice $(\mathrm{r}=0.174, \mathrm{p}<$ $0.001)$ and attitude-practice $(r=0.134, p<0.05)$. The result reaffirms the relationship between knowledge attitude and practice as shown in Table 6 .

\begin{tabular}{|l|l|l|}
\hline \multicolumn{3}{|l|}{ Table 6 Correlation between knowledge,attitude \& practice scores } \\
\hline Variable & Correlation coefficient & P-Value* \\
\hline Knowledge- Attitude & 0.249 & 0.000 \\
\hline Knowledge- Practice & 0.174 & 0.001 \\
\hline Attitude - Practice & 0.134 & 0.010 \\
\hline
\end{tabular}

${ }^{*}$ Correlation significant at $<0.05$ level $(2$ tailed).

\section{Discussion:-}

The current study sought to evaluate KAP towards HB among healthy individuals. Results of the study revealed an average KAP towards HB. The mean knowledge score was $14.15 \pm 4.66$ indicating borderline level of knowledge towards HB among the study cohort. Most of the respondents actually knew about transmission of HB but being health care workers should have a better knowledge about the same. Lack of knowledge about HB transmission can be attributed to rise in the frequency of HB.16.7\% of the participant did not believe that HB can cause liver cancer, which is again a major sign of concern. The primary source of informationwas through colleagues $\&$ seniors. These results are in line with findings from studies in Egypt Shalaby et al. (2007) who reported that participants had adequate knowledge towards transmission, vaccination and treatment of HB [35]. These results are in contrary with the findings from studies reported from parts of Pakistan where the overall knowledge of the general population regarding $\mathrm{HB}$ was reported low [25,26]. Similar to what is reported from Pakistan, poor knowledge regarding HB also is also reported around the globe [27-34]. Possible reasons that can be attributed to this difference of response are demographic variation of the study population, study location and as well as the study tool used for data collection. In addition, mean attitude score was also found average in the study participants who were actually healthcare workers against the general population in other studies. Some of the participants reported to use complementary and alternative medicines if infected with HB though being the backbone of allopathic medicine. Home remedies, herbal and traditional therapies were the treatment of choice until there is no improvement in the sign and symptoms of HB. Consulting the physicians was sought as the last resort, when all other healing system fails to provide cure. This is similar to what is reported by a study of same nature in Pakistan [25]. It is imperative to account that delay in seeking medical treatment for the infection results in further deterioration of the condition and can cause spread of infections. An important feature of patient care revolves around the Health Belief Model which highlights individuals' attitudes and beliefs responsible for particular health behavior [36]. In addition, perceived benefits and barriers in the health care regimen play a vital role in achieving therapeutic success. Results from the current study revealed that the some part of the population is in habit of making independent assessments of their current health status and were favoring different health systems (spiritual healers, yunani, ayurvedic and homeopathic healing systems) resulting in medical pluralism. Multiple opinions from such entities can complicate and disseminate irrational information and practices towards HB in the population and that too especially when allopathic ground level healthcare workers hold such belief. Although some of the systems are not approved by the official authorities in India, their influence is pronounced in the population. The results not with standing, it is important that the female multipurpose healthcare workers should be educated on all aspects of HB rather than on a single or a few issues. It is worth noticing that even after being ground level health care workers $9.8 \%$ of the respondents had not even heard of Hepatitis. Issues like these should also be addressed by social and medical researchers foregoing achieve a fuller understanding of the underlying issues while the outcome of such studies should be utilized in policy and decision-making by government officials and members of the health care team. Within this context, poverty, cultural beliefs and perceived severity of illness can be the reasons of seeking alternative methods of treatment. Though not infected yet, majority of the participants perceived HB treatment as costly. This could be due to their experiences with friends and family members having difficulties in bearing the cost of HB treatment. Cost of treatment is another factor which forces the patients to seek help from traditional healers. In developing countries like India, access to the traditional healers is economical than seeking treatment at medical health care facilities. Participants of the current study showed borderline practice towards HB. Some of the participants were not concerned about the safety measures which defiantly expose them to the danger of acquiring 
HB infection. Despite having awareness regarding the availability of HB vaccines and themselves involved in the job, nearly one-third of the participants were not immunized against HB. Similar results were reported by Razi and colleagues in 2010 from Pakistan [37] and Kabir et al. in 2010 from Iran [38] where the participants reported to have poor practices which were directly related to the knowledge and awareness regarding HB infection. On the contrary, Shalaby et al. (2007) in Egypt reported that the participants have good practice regarding hepatitis B hence have lower prevalence of infection [35]. Furthermore, the knowledge among participants was reported adequate by Shalaby et al., which is proportionately related to the attitude and practices of the participants. Age was significant factor associated the mean Knowledge \& Attitude scores, while education was a significant factor associated with mean Attitude \& Practice Scores. Cheung et al. in 2005 and Wu et al. in 2007 reported education level as the significant factor associated with KAP scores of their study participants [29,39]. The positive correlations between knowledge-attitude, knowledge-practice and attitude-practice in this study reaffirm the relationship between knowledge attitude and practice with infection control measures. It is concluded that adequate knowledge can lead to positive attitude resulting in good practices. The findings are in line with the results presented by Singh et al. in $2010[40]$.

\section{Conclusion:-}

Summarizing the results of this study, these findings indicate a borderline level of understanding of the basics of infection control and the prevention of transmission of HB in female multipurpose health care workers. Extensive health education campaign should be provided to FMPHWs. We recommend the adaptation of collaborative care where physicians, public health specialists should play their role in providing $\mathrm{HB}$ education to the healthcare workers. Empowering the people by providing them ample education and targeting at least one member of each family to have adequate information about $\mathrm{HB}$ can help in managing and controlling the infection.

\section{Limitations:-}

The study was conducted in one city and therefore results of the research are not representative of the entire population of Kashmir valley.

\section{References:-}

1. World Health Organization: Hepatitis B. Fact sheet no: 204. http://www.who.int/mediacentre/factsheets/fs204/en.

2. Lok ASF, McMahon BJ: Chronic hepatitis B. Hepatology 2007, 45:507-539.

3. Lee WM: Hepatitis B virus infection. N Engl J Med 1997, 337:1733-1745.

4. Mahoney FJ: Update on diagnosis, management, and prevention of hepatitis B virus infection. Clin Microbiol Rev 1999, 12:351-366.

5. Keeffe EB, Dieterich DT, Han SHB, Jacobson IM, Martin P, Schiff ER, Tobias H:

6. A treatment algorithm for the management of chronic hepatitis B virus infection in the United States: 2008 update. Clin Gastroenterol Hepatol2008, 6:1315-1341.

7. Lok ASF, McMahon BJ: Chronic hepatitis B: update 2009. Hepatology 2009,50:661-662.

8. Lesmana LA, Leung NWY, Mahachai V, Phiet PH, Suh DJ, Yao G, Zhuang H:Hepatitis B: overview of the burden of disease in the Asia Pacific region.Liver Int 2006, 26:3-10.

9. Mohamed R, Desmond P, Suh DJ, Amarapurkar D, Gane E, Guangbi Y, Hou JL, Jafri W, Lai CL, Lee CH, Lee SD, Lim SG, Guan R, Phiet PH, Piratvisuth T, Sollano J, Wu JC: Practical difficulties in the management of hepatitis B in the Asia-Pacific region. J Gastroenterol Hepatol 2004, 19:958-969.

10. André F: Hepatitis B epidemiology in Asia, the middle East and Africa.Vaccine 2000, 18:S20-S22.

11. Tandon BN, Acharya SK, Tandon A. Epidemiology of hepatitis B virus infection in India. Gut. 1996;38(Suppl 2):S56-S59.

12. Puri P. Tackling the Hepatitis B Disease Burden in India. Journal of Clinical and Experimental Hepatology. 2014;4(4):312-319. doi:10.1016/j.jceh.2014.12.004

13. Rajani M, Jais M. Magnitude and Pattern of Hepatitis B Infection in Clinically Suspected Infectious Hepatitis at a Tertiary Care Hospital in Urban India. Journal of Global Infectious Diseases. 2014;6(3):105-108. doi:10.4103/0974-777X.138502.

14. Mehra A, Private Sector in Health. Role of The Private Sector in Health Care in India- Present \& Future, Medical Director, India Aeromedical Services Pvt. Ltd., http://medind.nic.in/haa/t08/i1/haat08i1p2.pdf 
15. World Health Organization: Advocacy, communication and social mobilization for TB control: a guide to developing knowledge, attitude and practice surveys.http://whqlibdoc.who.int/publications/2008/9789241596176_eng.pdf.

16. Good B: Medicine, rationality, and experience: an anthropological perspective.Cambridge: Cambridge Univ Pr; 1994.

17. Tannahill A: Beyond evidence-to ethics: a decision-making framework for health promotion, public health and health improvement. Health Promot Int 2008, 23:380-390.

18. Ribeaux P, Poppleton SE: Psychology and Work: an introduction. London:Macmillan; 1978.

19. Yoder PS: Negotiating relevance: belief, knowledge, and practice in international health projects. Med Anthropol Q 1997, 11:131-146.

20. Ethical guidelines for biomedical research on human participants. http://icmr.nic.in/ethical_guidelines.pdf

21. Alam M, Tariq WUZ: Knowledge, Attitudes and Practices about Hepatitis B and C among young healthy males. Pak J Pathol 2006, 17:147-150.

22. Behling O, Law KS: Translating questionnaires and other research instruments: Problems and solutions. California: Sage Publications, Inc; 2000.

23. Harkness JA, Schoua-Glusberg A: Questionnaires in translation. ZUMA-Nachrichten Spezial 1998, 3:87-127.

24. Santos JRA: Cronbach's alpha: A tool for assessing the reliability of scales.J Extension 1999, 37:1-5.

25. Cohen J: Statistical power analysis for the behavioral sciences. In. $2^{\text {nd }}$ edition Edited by Hillsdale NJ. New Jersey: Lawrence Erlbaum; 1988.

26. Talpur AA, Memon N, Solangi R, Ghumro A: Knowledge and attitude of patients towards hepatitis B and C. Pak J Surg 2007, 23:162-165.

27. Haider G, Haider A: Awareness of women regarding hepatitis B. J Ayub Med Coll 2008, 20:141-144.

28. Taylor VM, Choe JH, Yasui Y, Li L, Burke N, Jackson JC: Hepatitis B awareness, testing, and knowledge among Vietnamese American men and women. J Community Health 2005, 30:477-490.

29. Taylor VM, Tu SP, Woodall E, Acorda E, Chen H, Choe J, Li L, Yasui Y, Hislop TG: Hepatitis B knowledge and practices among Chinese immigrants to the United States. Asian Pac J Cancer Prev 2006, 7:313.

30. Wu CA, Lin SY, So SK, Chang ET: Hepatitis B and liver cancer knowledge and preventive practices among Asian Americans in the San Francisco Bay Area California. Asian Pac J Cancer Prev 2007, 8:127.

31. Thompson MJ, Taylor VM, Jackson JC, Yasui Y, Kuniyuki A, Tu SP, Hislop TG: Hepatitis B knowledge and practices among Chinese American women in Seattle, Washington. J Cancer Educ 2002, 17:222-226.

32. Nguyen TT, Taylor V, Chen MS Jr: Bastani R, Maxwell AE, McPhee SJ:Hepatitis B awareness, knowledge, and screening among Asian Americans. J Cancer Educ 2007, 22:266-272.

33. Lim HC, Rashwan H: Awareness of Hepatitis A and Hepatitis B among Residents in Kuala Lumpur and Selangor. Malaysian Journal of Pharmacy 2003, 1:76-85.

34. van der Veen YJJ, Voeten HACM, de Zwart O, Richardus JH: Awareness, knowledge and self-reported test rates regarding Hepatitis B in Turkish-Dutch: a survey. BMC Publ Health 2010, 10:512.

35. Leung C, Wong W, Chan K, Lai L, Luk Y, Lai J, Yeung Y, Hui W: Public awareness of hepatitis B infection: a population-based telephone survey in Hong Kong. Hong Kong Med J 2010, 16:463.

36. Shalaby S, Kabbash I, El Saleet G, Mansour N, Omar A, El Nawawy A: Hepatitis B and C viral infection: prevalence, knowledge, attitude and practice among barbers and clients in Gharbia governorate, Egypt.East Mediterr Health J 2007, 16:10-17.

37. Saleem F, Hassali MA, Shafie AA, Awad AG, Bashir S: Association between knowledge and drug adherence in patients with hypertension in Quetta, Pakistan. Trop J Pharm Res 2011, 10:125-132.

38. Razi A, Ur Rehman R, Naz S, Ghafoor F, Khan MAU: Knowledge attitude and practices of university students regarding hepatitis B and C. ARPN Journal of Agricultural and Biological Science 2010, 5:38-43.

39. Kabir A, Tabatabaei SV, Khaleghi S, Agah S, Kashani AHF, Moghimi M, Kerahroodi FH, Alavian SH, Alavian SM: Knowledge, attitudes and practice of iranian medical specialists regarding hepatitis B and C. Hepat Mon 2010, 10:176-182.

40. Cheung J, Lee TK, Teh CZ, Wang C, Kwan W, Yoshida EM: Cross-sectional study of hepatitis B awareness among Chinese and Southeast Asian Canadians in the Vancouver-Richmond community. Can J Gastroenterol 2005, 19:245-249.

41. Singh A, Purohit B: Knowledge, Attitude and Practice towards Infection Control Measures and it's Correlation among Dental Students in Bhopal city, Central India. International Journal of Infection Control $2011,7$. doi:doi:10.3396/ijic.V7i1.007.11. 